\title{
GENETIC DIVERSITY OF NATURALLY GROWING WILD PLUM (PRUNUS DIVARICATA LEDEB.) GENOTYPES
}

\author{
Aydin Uzun ${ }^{1 *}$, Hasan Pinar ${ }^{1}$ \\ Erciyes University, Department of Horticulture, Kayseri, Turkey
}

Current Trends in

Natural Sciences

\begin{abstract}
Turkey is one of the genetic centers of several plum species including, $P$. cerasifera, $P$. instita, $P$. domestica and $P$. spinosa. Plum species grown in Turkey has very diverse plant features varied between shrubs and large tree, spreading to upright tree form and diverse blooming time. In present study, genetic variation among 16 wild plum ( $P$. divaricata) genotypes naturally grown around Erciyes mountain in Central Anatolia were investigated by using inter-simple sequence repeat (ISSR) markers. DNA was extracted from young leaves by the CTAB method. Fifteen ISSR primers produced clear fragments were used for the study. PCR reaction components, PCR cycling parameters, electrophoresis and gel imaging procedures were performed. A $100 \mathrm{bp}$ standard DNA ladder was used for estimating sizes of fragments. Data of molecular analyses were performed as follows: Bands obtained from ISSR primers were scored based on their scorability. Cluster analysis was performed in accordance with unweighted pair group method with arithmetic averages (UPGMA) method and dendrogram was created with NTSYS pc 2.11 software. using 15 primers of 119 bands obtained, 102 were polymorphic (87.6\%). The unweighted pair-group method arithmetic average analysis demonstrated that the genotypes had a similarity range from 0.66 to 0.89 . High level of genetic diversity was observed among plum materials. This diversity may be due to seed based propagation of the genotypes. These wild plum genotypes can be used for the expansion of the gene pool and breeding studies.
\end{abstract}

Keywords: genetic analysis, ISSR, wild plum

\section{INTRODUCTION}

Prunus subgenus located in Prunus genus divided into European plums (section Prunus), the North American plums (section Prunocerasus) and the apricots (section Armeniaca). Prunus section contains 20 species, which occur in three levels of ploidy, diploid $(2 n=2 x=16)$, tetraploid $2 \mathrm{n}=4 \mathrm{x}=32)$ and hexaploid $(2 \mathrm{n}=6 \mathrm{x}=48)$ (Reales et al., 2010). One of the Prunus species, cherry plum, (Prunus divaricata Ledeb.), is a wild growing, diploid, self-incompatible fruit tree. It was reported that the species is widely distributed from the Balkan Peninsula across Anatolia and the Caucasus to Central Asia, including the northern Iran (Browicz, 1969, Wohrmann et al., 2011). The plant can grow along the mountain slopes in woody or shrubby forest thickets, stony slopes and bottoms of ravines, near water, mountain river valleys (Batsatsashvili et al., 2017). This species is used as rootstock for plum and peach cultivars. Considerable variability in their fruits and kernels characteristics making them good candidates for domestication. Nevertheless, $P$. divaricata is a valuable fruit tree, only little research efforts have yet been dedicated (Khoshbakht et al., 2007). Turkey has rich plant genetic resources including, many wild, transitional and perennial herbaceous 
and woody plants because of located in two gene centers (Near East and Meditarranean) (Agaoglu et al., 1997; Ercisli, 2004). Among other species of wild fruits $P$. divaricata are also grown in various regions of Turkey. One of the areas where this species grows naturally is mountainous slope areas on the foothills of Mount Erciyes in Central Anatolia. Here, P. divaricata is found in the form of bushes, mostly in bushy forest areas. These populations have not yet been studied in terms of genetic diversity. In this study genetic variations of $P$. divaricata genotypes collected from high altitude in Kayseri province of Central Anatolia region were examined.

\section{MATERIALS AND METHODS}

In the study, $16 P$. divaricata genotypes were used. Genotypes are located in high altitude mountainous regions at the foothills of the Erciyes mountain, which are natural habitats.

\section{DNA extraction and ISSR analysis}

We extracted DNA from young leaves of 16 genotypes by the CTAB method as described by Doyle and Doyle (1990). DNA concentration was measured with a microplate spectrophotometer (BioTek Instruments, Inc. Vinooski, USA), and $10 \mathrm{ng} / \mu \mathrm{L}$ DNA templates were made using TE (10 mM Tris- $\mathrm{HCl}, 0.1 \mathrm{mM}$ EDTA, pH 8.0). The 15 primers were used to amplify the all of the accessions (Table 2). PCR reaction components and PCR cycling parameters were performed as described by Uzun et al. (2009). PCR products were separated on $2 \%$ agarose gel in $1 \times$ Tris/ Borate/EDTA (TBE) buffer (89-mM Tris, 89-mM boric acid, and 2-mM EDTA) at $115 \mathrm{~V}$ for 3-4 h.

\section{Data analysis}

Visualized bands under the UV light were scored as present (1) or absent (0) and data were analyzed with the Numerical Taxonomy Multivariate Analysis System software package (NTSYSpc version 2.1, Rohlf, 2000). A similarity matrix was constructed using ISSR data based on Dice's coefficient (Dice, 1945) which considers only one to one matches between two taxa for similarity. The similarity matrix was used to construct a dendrogram using the unweighted pair-group method arithmetic average (UPGMA) to determine genetic relationships among the germplasm studied.

\section{RESULTS AND DISCUSSION}

Totally 119 bands with high intensity were scored. The number of bands scored per primer combination ranged from $3\left((\mathrm{CAC})_{6}\right.$ and $\left.\mathrm{VHV} 6(\mathrm{TG})_{7}\right)$ to $13\left((\mathrm{AGC})_{6} \mathrm{G}\right)$, with a mean of 7.9. Polymorphic fragments numbers were 102 for primers and polymorphism was $87.6 \%$ (Table 1).

Using ISSR data similarity matrix was calculated according to Dice's coefficient (Dice 1945). Similarity dendrogram was constructed with UPGMA cluster analysis (Figure 1). Similarity values of accessions studied ranged from 0.63 to 0.99 . High level of diversity was observed and all genotypes were clearly distinguished. Genotype 13 and 14 were closest each other at 0.89 similarity level. Dendrogram was divided two main groups. The first group consisted of seven genotypes (Genotype 9, 11, 12, 13, 14, 15, 16). Another group included 9 genotypes (1-8 and 10) and genotype 8 was distinct from others.

There is limited research on genetic diversity of this species. Wohrmann et al. (2011) also high level of variation among $P$. divaricata populations in Iran. They concluded that domesticated and cultivated species often show low levels of genetic variation as compared with their wild ancestors. Reales et al. (2010) performed a phylogenetic analysis on members of the section Prunus including two $P$. divaricata accessions and three outgroup species using sequence data from four single-copy phylogenetically informative chloroplast DNA regions. In that study $P$. divaricata was grouped with. $P$. cerasifera and $P$. ursina. 
Current Trends in Natural Sciences

Vol. 9, Issue 17, pp. 337-340, 2020

https://doi.org/10.47068/ctns.2020.v9i17.042

Current Trends in Natural Sciences (on-line)

ISSN: 2284-953X

ISSN-L: 2284-9521
Current Trends in Natural Sciences (CD-Rom) ISSN: 2284-9521 ISSN-L: 2284-9521

Table 1. ISSR primers, numbers of total and polymorphic fragments and polymorphism ratio obtained this study

\begin{tabular}{|c|c|c|c|}
\hline Primers & $\begin{array}{l}\text { Total Band } \\
\text { Number }\end{array}$ & $\begin{array}{c}\text { Polymorphic Band } \\
\text { Number }\end{array}$ & $\begin{array}{c}\text { Polymorphism ratio } \\
(\%)\end{array}$ \\
\hline$(\mathrm{CAC})_{3} \mathrm{GC}$ & 10 & 8 & 80.0 \\
\hline $\operatorname{DBDA}(\mathbf{C A})_{7}$ & 6 & 6 & 100.0 \\
\hline$(\mathrm{AG})_{8} \mathrm{~T}$ & 8 & 8 & 100.0 \\
\hline$(\mathrm{CAC})_{6}$ & 3 & 3 & 100.0 \\
\hline$(\mathrm{AG})_{7} \mathrm{YC}$ & 11 & 8 & 72.7 \\
\hline VHV6(TG) ${ }_{7}$ & 3 & 3 & 100.0 \\
\hline$(\mathrm{CA})_{6} \mathrm{AC}$ & 11 & 11 & 100.0 \\
\hline$(\mathrm{AGC})_{6} \mathrm{G}$ & 13 & 10 & 76.9 \\
\hline$(\text { GAA })_{6}$ & 6 & 4 & 66.7 \\
\hline$(\mathrm{GACA})_{4}$ & 6 & 6 & 100.0 \\
\hline$(\mathrm{CA})_{8} \mathrm{R}$ & 10 & 8 & 80.0 \\
\hline HVH $(\text { TCC })_{7}$ & 12 & 12 & 100.0 \\
\hline$(\mathrm{TCC})_{5} \mathrm{RY}$ & 8 & 3 & 37.5 \\
\hline$(\mathrm{GT})_{8} \mathrm{TG}$ & 5 & 5 & 100.0 \\
\hline$(G A)_{8} Y G$ & 7 & 7 & 100.0 \\
\hline Mean & 7.9 & 6.8 & 87.6 \\
\hline Total & 119 & 102 & - \\
\hline
\end{tabular}

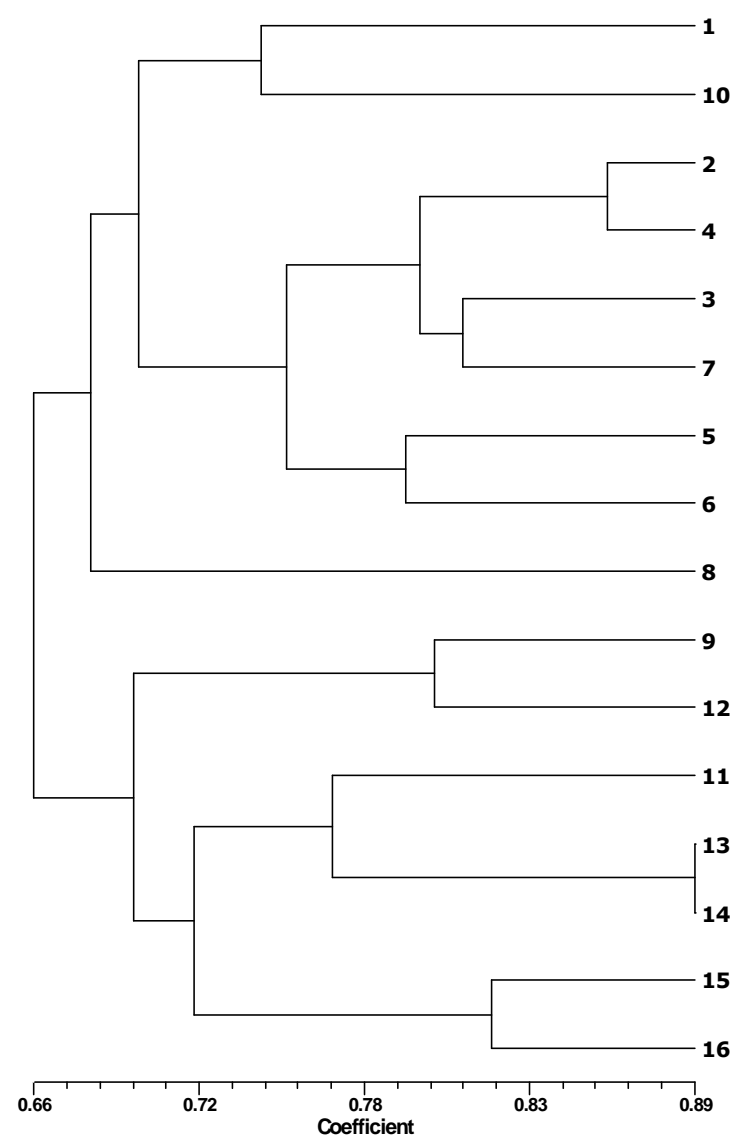

Figure 1. Dendrogram of the 16 P. divaricata genotypes using UPGMA method obtained from ISSR markers 


\section{Current Trends in Natural Sciences}

Vol. 9, Issue 17, pp. 337-340, 2020

https://doi.org/10.47068/ctns.2020.v9i17.042

Current Trends in Natural Sciences (on-line)

ISSN: 2284-953X

Current Trends in Natural Sciences (CD-Rom)

ISSN: 2284-9521

ISSN-L: 2284-9521

ISSN-L: 2284-9521

A wide variety has been determined in the mountainous and high altitude region where our study was conducted. This may be open pollination of plants and the transport and reproduction of seeds through natural vectors (birds and mammals). It was argued, the sweet and fleshy fruits of most fruit trees are dispersed by birds and mammals, leading to characteristically high levels of withinpopulation genetic variation (Wohrmann et al., 2011).

\section{CONCLUSIONS}

Our results indicated that $P$. divaricata grows naturally at high altitudes contain significant genetic diversity. The establishment of in situ and ex situ conservation programs for the conservation of this diversity is necessary. The use of wild species in breeding programs is very suitable for increasing the genetic diversity of cultivated cultivars and expanding the gene pool (Wolko et al., 2010; Wohrmann et al., 2011). P. divaricata can be used to increase diversity in cultivated Prunus species.

\section{REFERENCES}

Agaoglu, Y.S., Celik, H., Celik, M., Fidan, Y., Gulsen, Y., Gunay, A. et al. (1997). Genel Meyvecilik [General Fruit Growing]. A.U.Z.F. No: 4, 339 p.

Batsatsashvili, K., Mehdiyeva, N. P., Fayvush, G., Kikvidze, Z., Khutsishvili, M., Maisaia, I., Sikharulidze, S., Tchelidze, D., Aleksanyan, A., Alizade, V.M., Paniagua Zambrana, N.Y., Bussmann, R.W. (2017). Prunus divaricata Ledeb. in; Ethnobotany of the Caucasus (ed: Bussmann, R.W.) Springer International Publishing, Gewerbestrasse 11, 6330 Cham, Switzerland. ISBN 978-3-319-49411-1.

Browicz, K. (1969) Prunus L. In: Rechinger KH (ed) Flora Iranica, vol 66. Akademische Druck - und Verlagsanstalt Graz, Austria, pp 162-164.

Dice, L.R., (1945). Measures of the amount of ecologic association between species. Ecology, 26, $297-302$.

Doyle, J.J., Doyle, J.L. (1990). Isolation of plant DNA from fresh tissue. Focus, 12, 13-15.

Ercisli, S. (2004). A short review of the fruit germplasm resources of Turkey. Genetic Resources and Crop Evolution $51,419-435$.

Khoshbakht, K., Reza, M.A., Hammer, K. (2007). Phenotypic diversity of fruits and kernels of Prunus divaricata Ledeb. in Northern Iran-implications for domestication and utilisation. For: Tropentag, October 9-11, Witzenhausen.

Reales A., Sargent, D.J., Tobutt, K.R., Rivers, D. (2010). Phylogenetics of Eurasian plums, Prunus L. section Prunus (Rosaceae), according to coding and non-coding chloroplast DNA sequences. Tree Genetics \& Genomes, 6, 3745.

Rohlf, F.J. (2000). NTSYS-pc, numerical taxonomy and multivarite analysis system, version 2.11. New York, Exeter, Setauket.

Uzun, A., Yesiloğlu, T., Aka-Kacar, Y., Tuzcu, O. and Gulsen, O. (2009). Genetic diversity and relationships within Citrus and related genera based on sequence related amplified polymorphism markers (SRAPs). Scientia Horticulturae, 121, 306-312.

Wohrmann, T., Guicking, D., Khoshbakht, K., Weising, K. (2011). Genetic variability in wild populations of Prunus divaricata Ledeb. in northern Iran evaluated by EST-SSR and genomic SSR marker analysis. Genetic Resources and Crop Evolution, 58, 1157-1167.

Wolko, L., Antkowiak, W., Sips, M., Slomski, R. (2010) Self incompatibility alleles in Polish wild pear (Pyrus pyraster (L.) Burgsd.): a preliminary analysis. Journal of Applied Genetics, 51, 33-35. 